\title{
The Government Regulation of Economy Transformations in Terms of the Multinational Entrepreneurship Development and Technological Progress
}

\author{
Denis Ushakov \\ The Russian Presidential Academy of National Economy and Public Administration \\ (South-Russia Branch), Rostov-on-Don, Russia
}

\begin{abstract}
In this paper, the mechanisms and principles of economic regulation from the classical and modern approaches standpoints were analyzed, the typical for world economic theory trends of the government's economic role elaboration, of the government regulatory authority, reducing in favor of market self-organization was argued. The transnationalization as a factor of government regulation mechanisms modernization was estimated and the perspectives of government and MNC interactions development in the modern world were evaluated. The recommendations for improving the government economical regulation infrastructure and mechanisms due to the conditions of economy globalizing, transnational business developing, technologies progressing were presented.
\end{abstract}

Keywords: government economy regulation, the government economic competences, the network of economic interactions, the social responsibility, the government regulation innovative modernization

Business transnationalization and active introduction of information technologies in economic interactions are essential trends of the world economic development on the present stage. Because of the effectiveness of traditional tools of state regulation is rapidly reducing, it requires the formation of new principles and infrastructural implementation of the government economic competences. The article provides a theoretical justification of government presence in the market with modern conditions, analyzes the directions of economic transformation functions of the state by the internationalization and informatization processes of economic relations.

The purpose of the study is to analyze the main approaches to justification of the state's role in market economy, to justify the inability of traditional mechanisms of state regulation of the economy using at the present stage of world economy development, to identify the trends of state regulation of market modernization in the context of transnational entrepreneurship development and technological progress.

\section{Evolution of the Principles of State Regulation of Economy}

Different views of economists on the role and importance of the state in the economy suggest making a

Denis Ushakov, Ph.D. in Economy, Professor, The Russian Presidential Academy of National Economy and Public Administration (South-Russia Branch).

Correspondence concerning this article should be addressed to Denis Ushakov, 18/143 Wish@Samyan condominium, Si Praya road, Mahapruktharam, Bangrak, Bangkok, 10500, Thailand. E-mail: fintaliano@mail.ru. 
conclusion that none of them exclude the government out of the market economy system. Its place and role, methods, means and forms of participation in the economy in different theories are different, but somehow it is always present in the economic system.

Analysis shows that the views of the economic schools on the state role in the economy in different conditions of social development, it is substantially changed. This was due to, above all, transformation the goals of social progress in specific historical periods, market fluctuations and economic relations as an object of state regulation and the unit of the state (political system, the state of the state apparatus, the degree of corruption, etc.) as the subject of this management.

The constancy of the purposes of state regulation of the economy (the alignment of economic cycles, enhancing the development of productive relations, national wealth, the elimination of the negative effects of increasing monopolization and differentiation of incomes received by members of the society, etc.) provided in different historical periods through the application of fundamentally different instruments.

Initially, these were the restrictions of foreign trade, formed the basis of protectionist policy. The government was an invisible participant of the foreign trade relations, receiving some benefits (in the form of customs duties and fees) due to, primarily, domestic consumers of imported goods, spending in the future these benefits and additional cost for the strengthening of national wealth (Mun, 1664; Malynes, 1614).

Later, the government role in the economy was reduced to the functions of "night watchman" (Smith, 1776; Ricardo, 1817) that provides effective conditions for the production and internal and external trade. At this stage, the tools of state regulation of economic relations were the business environment, the adequacy requirements of the market. It depends on the level of self-organization and efficiency. However, the market has received the status of ideal self-organizing system and entrepreneurial flair, put at the forefront of the process of achieving national prosperity, quickly showed the inability of the market self-development, requiring urgent review of government economic policy.

Since then, the tools of state regulation of the market in turn become separate components of the social and economic relations, the process of production and trade, through which the impact on the entire economic system recognized that more or less effective. Keynesians determined as the main object of state regulation of economic relations — demand (Keynes, 1936; Lindahl, 1954; Traill, 2008). They have elaborated a revolutionary for their time, theory of economic growth, based on state incentives for domestic consumption, as well as a system of multipliers and accelerators of economic development. Monetarists saw a way to achieve economic prosperity through the regulation of money supply, affecting to the quantity and quality of productive factors (especially investments), as well as to the potential demand (price level) (Friedman, 1970; Andersen, 1968; Laidler, 1993; Warburton, 1966; Ekelund, 1981). Finally, a more modern theories, especially defects (or failures) of the market altogether eliminated the state of market relations, limiting the range of its duties only to the maintenance of a competitive environment and solution of matters in respect of which private enterprise is meaningless due to the lack of commercial interest of market agents.

Thus, the evolution of state economic regulation indicates-Firstly, the growing detailization of government role, and secondly, the gradual movement of the object of state regulation from the final phases of the productive process to its starting. If to imagine the market process as a chain of stages (identification of productive factors, evaluation of market and productive activity conditions, productive process and trade), we can easily identify the 
desire of each new approach to determine the object of governance closer to the start of this chain.

Mercantilists admitted a great degree of market self-organization in respect to the producer. Under their conclusions (Mun, 1664; Malynes, 1614), the only external trade-related import was limited, while the national producer (export-oriented and the domestic market) virtually had no restrictions. Moreover, government intervention in the function of internal market was not expected (except for its protection from foreign competitors).

The objects of government intervention, according to liberal views (Smith, 1776; Ricardo, 1817), were to be the conditions for business and public confidence in the impossibility of government changes of factors and the means of production. Almost all the conclusions of the founders of the liberal theory such as Adam Smith and David Ricardo began with the words "under specific conditions..." or "with the available resources...”, which is consistent with the spirit of that time, distinguished by immobility of productive factors and limited technologies. Proponents of liberalism considered the possibility of market self-organization only if the establishment and maintenance of certain starting conditions, without assuming that after a few centuries, state will has the opportunity to direct the course of the productive process.

Basing on the primary role of demand Keynesian theory gave it by the characteristics of the tool, stimulating and guiding economic development. Demand ability to organize course of entire productive process and market relations, as well as opened possibilities of state influence on the demand became the basis for the Keynesian model of state economic regulation.

Monetary concept is adequate to conditions of economically developed countries with efficient working of financial institutions. The mobility of productive factors (capital, labor, technologies), which significantly increased in the second half of the 20th century, due to scientific and technological progress and growth of information and telecommunication technologies, and identified the growth of the government potential to determine and direct the manufacturing process at a stage of its planning.

Thus, during the evolution of government economic regulation, its object was moving from the final (trade) to the initial (factors of production and as a tool of influence on them - the money supply) point of the productive process. It generally enhances the state's role as a "guide" of economic development, leaves fewer opportunities for market self-organization, and reduces the variability of economic development.

Figure 1 shows schematically the evolution of objects of state regulation of economy. These data represent the object of state regulation of the economy movement from the final to the initial stages of the productive process, which reduces the field of market self-organization.

In our opinion, the object of state regulation of economy does not determine the degree of liberality of government intervention in the economy. It depends on object of state competence and authority of the private business (a set of tools, the level of accountability of market agents, the degree of bureaucratization, the effectiveness of overcoming market failures, the appropriateness of measures to address flaws in the state).

Even the argument-what is more liberal monetarism or mercantilism-is meaningless and unfounded. Within one approach, there may exist models more or less liberal, while the fundamental differences among the approaches are totally at different levels.

The fifth model of state economic regulation, which is actively practiced today by some states, received the code name of the method of reagent spots or method of development points. It's meaning in the impact with the 
"holy of holies" of the market economy - the entrepreneurial interest. This model is typical for countries with liberal economic system that no one will doubt (for example, the USA, France, Germany, the UK), and new industrialized countries (South Korea, Singapore, Malaysia). It is based on the programming of the entire process of economic development and the exclusion of market self-organization in the classic concept.

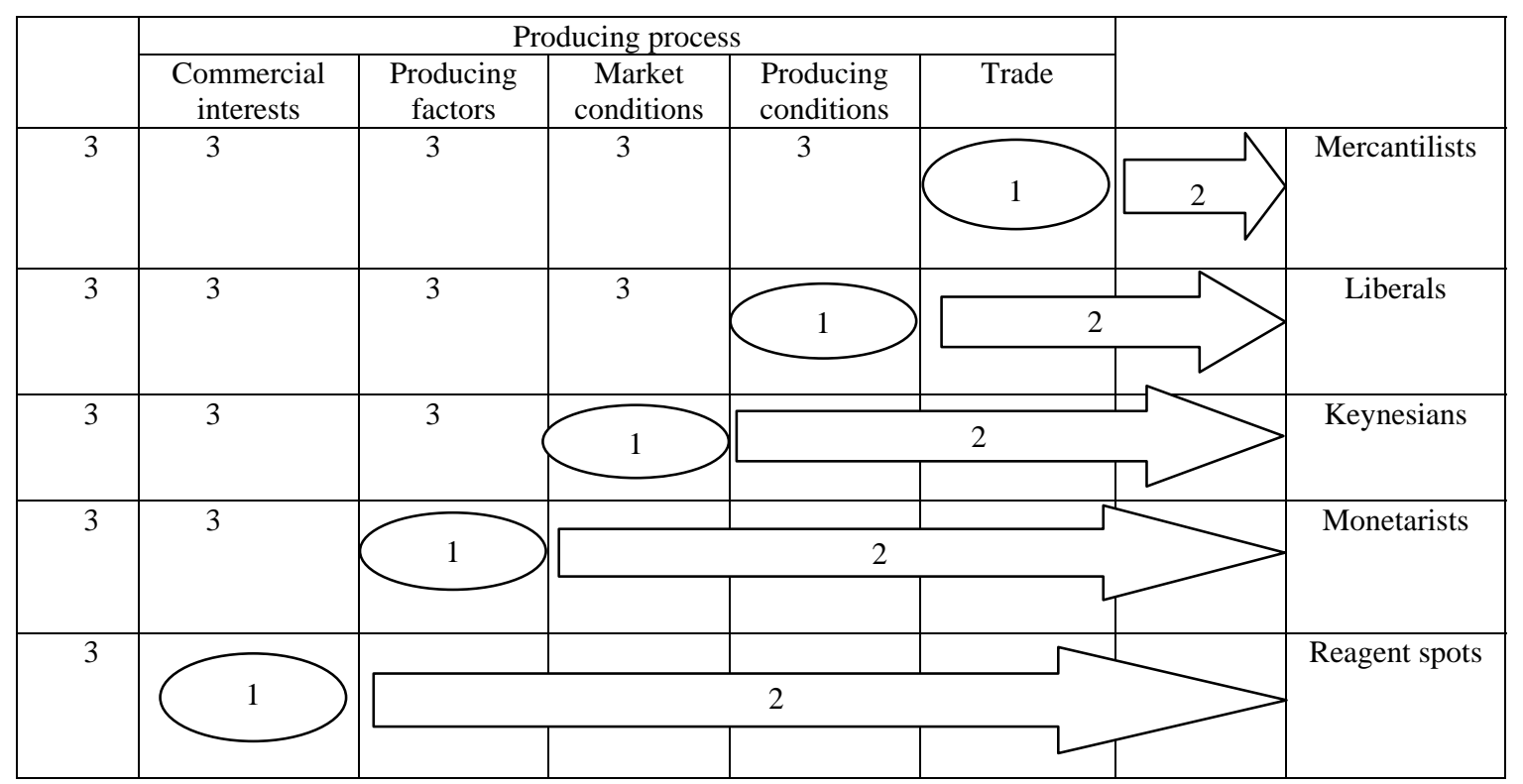

Figure 1. Objects of government economic regulation from the standpoints of the classical schools. Legends: Zone 1: Government regulation objects; Zone 2: Government regulated interactions; Zone 3: Market self-organization.

This model is relevant in modern environment characterizing by the globalization of world economy. Fully apparent in the 1990s, economic globalization has affected all spheres of human activity. It is clear that strong causal union of globalization and post-industrialization has turned the classic ideas about the productive process, competition on the market, consumption and trade. Certainly, it could not call and transform approaches to determining the place of the state in the national economy, which has become an integral part of the global.

\section{The World Economy Transnationalization as a Factor of State Regulation Modernization}

Application of traditional measures of economic regulation for the MNCs from national governments is extremely inefficient. Thus, the levers of the financial sector (the value of the refinancing rate, central bank reserve rate) can affect the industries of the economy and business activity by means of indicators of the financial market. In respect of transnational corporations, they deprived of expediency due to the fact that MNC is able to attract the necessary funds for corporate development with any market that has more comfortable rates and liberal terms, and further to distribute them through the channels of intra-corporate interaction.

Tax instruments are traditionally effective in the national economy. In a global economy allowing the implementation of the export capital or profits abroad, under the jurisdiction of another, having a more liberal tax regime, are also ineffective tools.

The main reason for the loss of national states capacity to regulate transnational business in those states in their economic management continues to use the mechanisms of influence on the market, but within multinational companies any market relations do not exist. 
MNC replaced its intra-interaction about two-thirds of the international market, the share of intra-corporate transactions in world trade of goods and services continues to grow rapidly. This intra-interaction is similar to global trade, but is structurally and formally different.

Traditional market mechanisms, the laws of market trading, the interaction of market characteristics, such as supply and demand, are absolutely powerless in the rationale directions, structure and content of intra-flow values.

The traditional pricing (based on market equilibrium) is replaced by the policy of discriminatory prices. For example, similar goods, produced in the same venture, MNC, but intended for users of different countries, initially have different prices. Moreover, the market equilibrium as the key market category was transformed beyond recognition due to the sudden growth of the global mobility of productive factors as well as made products and the tremendous opportunities that have the brand owners of the planetary scale and high-hume-technologies that are actively used in demand stimulation.

In a globalizing economy, a basic principle of the market as commercial interest was substantially transformed. At the dawn of capitalist relations of healthy greed, obtaining profits stimulated entrepreneurs to invent new forms and areas of their own earnings, to optimize existing productive processes, to save costs, to invest in advertising to increase sales of product and to increase market share. In the beginning of the 21th century, large corporations have become increasingly realize the so-called strategy of "social responsibility".

The idea of corporate social responsibility began to emerge in western economies since the mid-twentieth century, when, caused by the rapid development of the market, the globalization of world economic, issues of social justice, wealth inequality eventually exposed. It became clear that the traditional economy and the market, even in global terms, are unable to overcome these problems. Features of the state, dependent of its financial capacity, of the performance of big business, in solving the social problems also were significantly limited and insufficient to the full. In this situation, the care of individual social problems begin to learn the corporation itself, they also begin to actively promote their own social responsibility as a kind of competitive advantage, a promotional tool, a way to consolidate the loyalty of the client audience and market power.

Thus, at the end of the last century, formed a kind of radically new form of involvement of social responsibility in the orbit of the commercial interests of business. Deductions of corporations to overcome social problems (the most popular of them were and still are, for example, the struggle for a clean environment, improving literacy of population, the implementation of labor standards in factories and so on), on the one hand, have no clearly defined commercial basis. They indirectly affect the performance of corporations through the formation of its positive image in the consumer market.

On the other hand, commercial interest substantially is transformed by the analogization of socially responsible and corporative successful. At the beginning of a new century, the corporation could not be socially responsible and, consequently, there could not be no denying the inability of the state to solve social problems and did not recognize the impotence of the authorities in overcoming market failures.

It is possible to agree, that the market, which is aimed to salvation the problems, stimulated by itself, is far from the markets, which were described by classics of economic theory.

In the new up-market relations, firstly, the government finally resigned themselves to their own inability to regulate the market economy and to overcome the failures of the market economy. Secondly, the rules of 
corporate social responsibility are also becoming a commodity and not an additional tax on business for the benefit of society, an instrument to additional pressure on both the authorities and competitors.

The transformation of social responsibility in the product, a new form of competitive advantage, does not really solve the global problems of mankind, which are reinforced every year, but actively influence on the global balance of economic forces, the formation of structure and trends of international trade and movement of productive factors.

The consequences of this trend are very vague and not always optimistic. State, losing the last facilities of its own impact, firstly, put an end to the possibilities of strategic planning for economic and social development, and implementation of activities aimed at achieving of strategic goals and objectives. Secondly, the "socially responsible" business increases the gap between the state and corporations, with the last starting to look more attractive and persisting in the new economic conditions.

\section{Directions for Modernization of Government Regulation of Economy}

In the defined conditions for the world economic development, feeling the number of threats to its own existence, the state, in order to preserve its own economic and social importance, must change the principles and infrastructure implementation of its regulatory functions. It is worth noting that not only the rapid development of transnational business stimulates the formation of threats to the existence of the states. At the same time, a factor of transformation of state regulation is the informatization of economic relations, the penetration of information technologies in economic interactions.

Thus, the introduction of information technologies can eliminate a number of significant market failures that were previously within the boundaries of state regulation. Among these failures, the most significant thing is the asymmetry of information distribution to participants of market relations, which completely disappears in the information economy. Now anyone can gain access to global information resources, but inefficiency of the global implementation of protection of intellectual property rights creates additional conditions to eliminate the information asymmetry of branch markets. National governments no longer need to regulate the processes of information security of national enterprises, for them this function has assumed a global information market, whose instruments have become more effective than in the hands of officials.

The second most important area of state economic regulation is the so-called market inability to produce the necessary social, public benefits. One of the key features of public goods-their so-called "non-exception”, that is impossible to prohibit to consumers to use the benefit, regardless of whether they pay for it or not. Technological development significantly reduces the cost of collecting funds and thus narrows the range of non-exclusive benefits. Thus, information technologies allow to define the number of people asking for free medical care, benefiting from a modern highway, the services of the theater or museum and to have a specific dossier on everyone in the country or locality.

Technologies contribute to increasing of the effectiveness of government measures aimed at, for example, to maintain certain social strata of the population, stimulating the development of priority sectors of the economy, management of state and municipal property, and so on. Establishment of a national (and ultimately global) database will cause a sharp increase in the targeting of government subsidies, grants, pensions, social benefits, but the development of network communications, integration of communications and financial spheres 
necessarily lead to complete automation of even the process of transfers and payments to the population. Efficiency growth of state regulation through greater targeting of social programs, eligibility by the state actual information, acceleration, and individualization of feedback from people, reducing the bureaucratic state apparatus will inevitably lead to decreasing budget, their more appropriate use.

The unity and universality of the virtual space, the impossibility of carrying out business without information networks will allow the government to control almost all economic interactions, have a local information resource on which to develop measures of national economic policy. Transfer of production, trade, foreign economic activity in the virtual sphere repeatedly reinforce the possibility of state control, reducing budgetary costs, increasing efficiency of economic policy. In a virtual environment, using the software can track the trade and financial flows, assess the correctness of documentation, the financial position of enterprises, implement narrow-specialized, having individual object programs of government incentives and support, and so on.

Reducing of government expenses and a simultaneous increase in revenues, for example, the transparency of the information economy will increase the efficiency of tax collection and management of enterprises under state ownership, will make it more useful to the process of regulation of natural monopolies and the auctions, the distribution of quotas and bidding can cause systematic liberalization of tax regimes, foreign trade, the process of cross-border movement of capital. It will significantly increase the investment attractiveness and efficiency of national production.

As evidence of the reality of implementing virtualization software government regulation of the economy, can result in a single trade and logistics system, created by the corporation Wall-Mart. Items offered for shelves of networks has an individual barcode. After selling, the barcode is read out and falls into a single information network of the corporation. Data of the sale of units that are fed to the warehouse where, during the day is formed by an order under which the delivery of goods from a warehouse in the corresponding shopping mall. One database enables companies to optimize the internal logistics, the range of offers in supermarkets, plan marketing programs and then track their performance.

The corporation database also includes personal data of customers, paying by credit cards or having special discount cards to the Wall-Mart, which is formed on the basis of client base, steady communication with each of the millions of consumers, characterized by a preference of age segments of buyers, the intensity of consumption of a product in a certain area. It can further contribute to the optimization of advertising, promotion and product mix.

For example, the Wall-Mart can be seen that a transparent internal information environment in the company, the Board had not only repeatedly lowered transaction costs, build profits, but also turned its face to the corporation customers, turned it into a well-functioning with regulated internal interaction mechanism practically devoid of the ability of the downtime and disruption. Similar model can be implemented within the state, its economic system.

The most important condition for informatization of the economy besides creating appropriate technological infrastructure is a powerful set of measures initiated by the state aimed at encouraging corporations to expand the scope of their virtual life.

To the virtual sphere it must be submitted:

- Capacity of private companies with their target in the database features of their market value, productivity, demand for raw materials and so on; 
- Information about deliveries of raw materials from the relevant suppliers;

- Data on the output of finished products;

- A database of consumers, distributors and agents.

Virtualization economy requires a transfer into a network of financial relations, the implementation in network of all possible calculations, including those with foreign partners and investments, loans and mortgages.

The state with the largest high-tech companies should create a database of all population and enterprises in the country and foreign (such as end-users), with a view to the ultimate virtual chain and consumption of gross domestic cost. It also actively should participate in bringing private business into the virtual area, arguing the need for such transition potential abrupt increases in business efficiency (by reducing transaction costs, acquiring of new capabilities for personalized marketing programs, current and strategic planning, access to relevant statistical information).

Transferring the economy, the state will have not only significant improvement of the transparency of economic interactions and enhance the effectiveness of its own regulatory actions, but also provide tools for optimizing the inter-sectoral collaboration. For example, computerized economy will be possible to avoid crises of overproduction or the phenomenon of commodity or cash deficit to debug the system of internal or international logistics, to create a unified system of passenger and freight traffic, to reallocate effectively funds among sectors and so on.

\section{Conclusions}

The study of conceptual frameworks of state economic regulation in terms of internationalization of business, scientific and technological progress, allows drawing some conclusions about the transformation of infrastructure and implementation of the principles of regulatory competences of governments.

Firstly, according to the existing approaches to the theoretical grounding of state presence in the market in modern conditions of the government is required to specify the maximum of their own economic functions, their implementation, taking into account the possibility of connecting with the mechanism of market self-organization in the nearest future.

Secondly, in terms of internationalization, the traditional instruments of state economic regulation lose their effectiveness. It requires the government to transfer the process of implementation of regulatory competences on the network basis, to enhance their social role (as opposed to social initiatives MNC) to concentrate on the formation conditions of socio-economic progress of the society, domestic consumption.

Thirdly, with the growth of information economy, the state needs transform into an active user of the information product, form an adjustable virtual sphere, with a further incentive of transfer in it business and productive activity of corporations.

One should mention that the selected recommendations are not so factors for the improving of effectiveness of state regulation in modern conditions, as factors in preserving of the state economic role in whole.

\section{References}

Andersen, L. C., \& Jerry, L. J. (1968). Monetary and fiscal actions: A test of their relative importance in economic stabilization. Federal Reserve Bank of St. Louis Review (November), 11-24.

E-Commerce and Development Report. (2009). Geneva: UNCTAD. 
Ekelund, R. B., \& Tollison, R. D. (1981). Mercantilism as a rent-seeking society: Economic regulation in historical perspective. College Station, TX: Texas A\&M University Press.

Florida, R. (2004). The flight of the creative class. New York: Harper Business.

Gradobitova, L., \& Isachenko, T. (2002). Multinationals in the modern economy. Moscow: Ankhil.

Guriev, S. (2006). The myths of economy. Moscow: Alpina Business Books.

Keynes, J. (2007). The general theory of employment, interest and money. Basingstoke, Hampshire: Palgrave Macmillan.

Laidler, D. E. W. (1993). The demand for money: Theories, evidence, and problems (4th ed.). New York: Harpercollins.

Landreth, H., \& Colander, D. C. (2002). History of economic thought (4th ed.). Boston: Houghton Mifflin.

Lindahl, E. (1954). On Keynes' economic system. Economic Record.

Friedman, M. (1970). A theoretical framework for monetary analysis. Journal of Political Economy, 78(2), 210.

Montri, C. (2006). Iminovation ${ }^{T M}$. Bangkok. Thailand: National Innovation Agency.

Nambisan, S., \& Sawhney, M. (2008). The global brain. New Jersey: Wharton School Publishing.

Smith, A. (1976). The wealth of nations(R. H. Campbell, \& A. S. Skinner, Eds.). The glasgow edition of the works and correspondence of Adam Smith, 2a, 456.

Tapscott, D., \& Williams, A. (2006). Wikinomics: How mass collaboration changes everything. London: Penguin Books.

The Works and Correspondence of David Ricardo. (Ed.) (2005). Piero Sraffa with the Collaboration of M. H. Dobb (Indianapolis: Liberty Fund, 2005), 11, 1817.

Traill, R. R. (2008). Problems with economic rationalism -Psychology, green-issues, and jobs. Melbourne: Ondwelle. Warburton, C. (1966). Depression, inflation, and monetary policy: Selected papers, 1945-1953. Johns Hopkins Press. 